\title{
U-Pb geochronology of felsic volcanic rocks hosted in the Gafo Formation, South Portuguese Zone: the relationship with Iberian Pyrite Belt magmatism
}

\author{
D. R. N. Rosa ${ }^{1, \dagger} *$ A. A. Finch ${ }^{2}$, T. Andersen ${ }^{3}$ And C. M. C Inverno ${ }^{1, \dagger}$ \\ ${ }^{1}$ INETI-Geological Survey, Estrada da Portela-Zambujal, Alfragide, 2720-866 Amadora, Portugal \\ ${ }^{2}$ School of Geography and Geosciences, Irvine Building, North Street, St Andrews, Fife, KY16 9AL, UK \\ ${ }^{3}$ Department of Geology, University of Oslo, PO Box 1047 Blindern, N-0316 Oslo, Norway
}

[Received 8 July 2008; Accepted 23 December 2008]

\section{ABSTRACT}

Felsic volcanic rocks hosted in the Frasnian Gafo Formation, from the Azinhalinho area, display very similar geochemical signatures to volcanic rocks from the Iberian Pyrite Belt (IPB), located immediately to the South. The similarities include anomalously low HFSE concentrations, possibly caused by low temperature crustal melting, which translate into classification problems.

A geochronology study, using LA-ICP-MS analyses of zircon grains from these rocks, has provided concordia ages of $356 \pm 1.5 \mathrm{Ma}$ and $355 \pm 2.5 \mathrm{Ma}$ for two samples of rhyodacite porphyry, and $356 \pm 1.4 \mathrm{Ma}$ for a granular rhyodacite. These results show that volcanism at Azinhalinho was broadly contemporaneous with IPB volcanism, widely interpreted as being of Famennian to Visean age. Considering that the host rocks of the Azinhalinho volcanic rocks are Frasnian, and therefore deposited synchronously with the Upper Devonian Phyllite-Quartzite Group sedimentation in the IPB basin, the radiometric ages imply that the Azinhalinho felsic rocks are intrusive and likely represent conduits or feeders to the volcanism of the IPB.

Keywords: U-Pb, zircon, geochronology, LA-ICP-MS, Iberian Pyrite Belt.

\section{Introduction}

A series of small outcrops of felsic volcanic rocks occurs near the village of Azinhalinho, approximately $20 \mathrm{~km}$ South of Beja, Portugal (Fig. 1). This area is located in the transition between the Iberian Pyrite Belt (IPB) and the Pulo do Lobo Antiform. These two domains are both part of the South Portuguese Zone (SPZ), the southernmost tectonic unit of the Iberian Massif of the Variscan

\footnotetext{
* E-mail: diogo.rosa@ineti.pt

$\dagger$ also at: Department of Geology $\overline{\bar{x}}_{\bar{\lambda}}$ CREMINERUniversity of Lisbon, Edifício C6, Piso 2, 1749-016 Lisboa, Portugal

DOI: 10.1180/minmag.2008.072.5.1129
}

Orogenic Belt (Julivert et al., 1972). The IPB is interpreted to correspond to an intracontinental rift zone related to an oblique subduction regime. As a result of the northward trending subduction, beneath the Ossa Morena Zone, an accretionary prism constituted by the Pulo do Lobo sediments developed.

Traditionally, the volcanic rocks from Azinhalinho have been interpreted as being within turbiditic shales and graywackes of the Frasnian Gafo Formation of the Chança Group (Pulo do Lobo Antiform), which was thrusted over younger formations of the IPB, immediately to the South (Oliveira et al., 1988, Oliveira et al., 2006). This has raised the question of whether the volcanic rocks from Azinhalinho correspond to an 
episode of volcanism that predated extrusive volcanism in the IPB or whether both sets of rocks were broadly synchronous, but the Azinhalinho volcanism was intrusive rather than extrusive.

In order to establish the relationship between the Azinhalinho volcanic rocks and volcanic rocks from the IPB, we report on the petrography, lithogeochemistry and radiometric ages of the former. This is particularly relevant as the volcanogenic massive sulphide (VMS) deposits of the IPB, which are among the largest of the world, are associated with felsic volcanic rocks. While some $\mathrm{U}-\mathrm{Pb}$ data on volcanic rocks from the IPB are available (Dunning et al., 2002; Barrie et al., 2002; Rosa et al., 2008), we report new radiometric data for the felsic rocks hosted in the Gafo Formation.

\section{Geological setting}

The volcanic rocks from Azinhalinho occur immediately to the SW of the quartzite-rich Pulo do Lobo Formation and associated Atalaia Formation (Fig. 1). The volcanic rocks occur within siliceous shales, greywackes and quartzwackes, which are interpreted as belonging to the Gafo Formation. According to Oliveira et al. (2006) and Pereira et al. (2006), the Gafo Formation yielded Lophozonotriletes media spores, corresponding to the BM Biozone of Frasnian age (374.5-385.3 Ma, Gradstein et al., 2004). Two apparently continuous bands of volcanic rocks run NW-SE, the north-easternmost containing intensely chloritized granular felsic to intermediate rock and the south-westernmost containing granular felsic rock (Fig. 1).

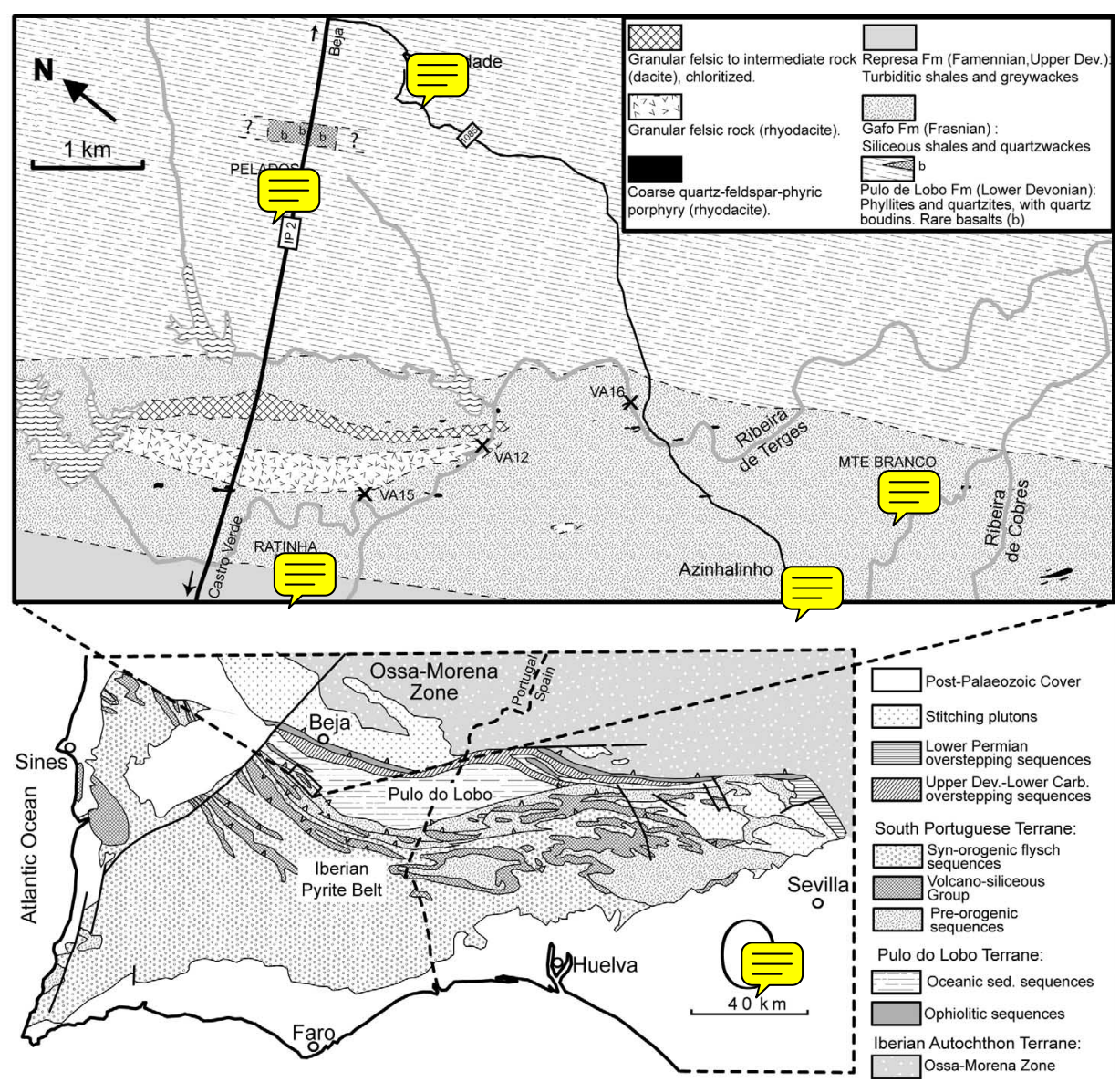

Fig. 1. Simplified geology of the South Portuguese Zone (modified after Quesada, 1991) and detail of the Azinhalinho area. 
Outcrops along these bands are poorly preserved and contacts with enclosing rocks are hard to observe, despite some continuous exposure along the Terges creek and the IP2 road. Additionally, small discontinuous tabular bodies of coarse quartz-feldspar-phyric porphyry occur throughout the area.

As the result of the Variscan orogeny, the area has been affected by low-grade regional metamorphism at greenschist facies (Munhá, 1990) and deformation is characterized by SW verging folds. We collected 8 samples of metasedimentary rocks from the Gafo Formation, and 26 samples of volcanic rocks hosted by that formation. Samples numbers were given the prefix VA and are now in the INETI collection in Portugal.

\section{Methods}

\section{Petrography and lithogeochemistry}

Thin sections of representative volcanic rock samples were prepared and a preliminary petrographic study conducted on them, using transmitted and reflected light microscopy. This study allowed to establish the mineral composition of these rocks and to characterize their textures. Additionally, cathodoluminescence (CL) observations were performed using a Technocyn Mark 4 cold cathode CL, attached to an optical microscope and a sensitive DVC1310-C CCD camera operated using $X C A P$-Lite software at the University of St Andrews, UK.

To complement the petrographic study, nineteen samples of volcanic rocks were subject to multielement analysis. These samples were crushed in a tungsten alloy jaw-crusher and subsequently pulverized in an agate ring mill. The obtained powders were analysed for a suite of trace elements at Actlabs, in Canada: $\mathrm{Au}, \mathrm{As}, \mathrm{Co}, \mathrm{Cr}$, Cs, Hf, Ir, Sb, Sc, Se, Ta, Th, U, W, La, Ce, Nd, $\mathrm{Sm}, \mathrm{Eu}, \mathrm{Tb}, \mathrm{Yb}$ and $\mathrm{Lu}$ by instrumental neutron activation analysis (INAA); and $\mathrm{Ag}, \mathrm{Cd}, \mathrm{Cu}, \mathrm{Mo}$, $\mathrm{Ni}, \mathrm{Pb}, \mathrm{Zn}, \mathrm{Be}, \mathrm{Bi}, \mathrm{V}$ and $\mathrm{S}$ by inductively coupled plasma optical emission spectroscopy (ICP-OES). Major elements and $\mathrm{Nb}, \mathrm{Zr}, \mathrm{Sn}, \mathrm{Ba}, \mathrm{Ga}, \mathrm{Rb}, \mathrm{Sr}$ and $\mathrm{Y}$ were determined by X-ray fluorescence (XRF) on fused discs, at the INETI laboratory in Porto, Portugal. Analyses of standards have shown that the values obtained on the unknowns are accurate. XRF provides a precision of better than $5 \%$, whereas Actlabs' internal duplicate results were shown to be within $10 \%$.

\section{Preparation and characterization of samples for geochronology}

Samples for the geochronology study were collected at the locations indicated in Fig. 1. Zircon grains were separated from samples using standard density and magnetic procedures, at the Department of Geography and Geosciences of the University of St Andrews and at the Department of Geosciences of the University of Oslo. These procedures included the crushing of samples in a jaw crusher, followed by sieving of the $<425 \mu \mathrm{m}$ fractions. The heavy minerals from these fine fractions were then separated using tetrabromoethane or hetero-polytungstate solution. Subsequently, the heavy mineral fraction was separated into fractions with different magnetic susceptibilities using a Frantz isodynamic separator. Finally, zircons were handpicked under a binocular microscope from the nonmagnetic fraction, mounted in epoxy and polished. Detailed imaging of each grain was carried out using CL and backscattered electron imaging, using a Jeol JSM-6460LV scanning electron microscope. Particular care was put into identifying inherited cores and limits between different generations of magmatic zircons, to ensure that analyses did not overlap different domains.

\section{LA-ICP-MS}

$\mathrm{U}-\mathrm{Pb}$ dating was performed using a $\mathrm{Nu}$ Plasma HR multicollector ICPMS at the Department of Geosciences, University of Oslo, which is equipped with a U-Pb collector block (for design details of the Nu Plasma U-Pb collector block, see Simonetti et al., 2005). A New Wave LUV213 Nd:YAG laser microprobe was used. Samples were ablated in $\mathrm{He}$ gas (gas flow $=$ $1.0 \mathrm{l} / \mathrm{min}$ ) in an ablation cell similar to that of Jackson et al. (2004). The He aerosol was mixed with $\operatorname{Ar}$ (gas flow $=0.71 / \mathrm{min}$ ) in a teflon mixing cell prior to entry into the plasma. The gas mixture was optimized daily for maximum sensitivity. All analyses were made in static ablation mode, with the laser beam focused in aperture imaging mode with a circular spot geometry. This produced circular, flat-bottomed ablation pits. U-Pb ages and $\mathrm{Hf}$ isotope data were determined individually on adjacent spots, using laser operating conditions (see below) which secured maximum preservation of the unablated part of the zircon. 
$\mathrm{U}-\mathrm{Pb}$ analyses were made according to analytical protocols described by Andersen et al. (2007) and Røhr et al. (2008). A single U-Pb measurement included $30 \mathrm{~s}$ of on-mass background measurement, followed by $60 \mathrm{~s}$ of ablation with a stationary beam. Laser conditions for $\mathrm{U}-\mathrm{Pb}$ analysis were: Beam diameter: $40 \mu \mathrm{m}$, pulse frequency: $10 \mathrm{~Hz}$, beam energy density: $\sim 0.06 \mathrm{~J} / \mathrm{cm}^{2}$. At these conditions, the depth-todiameter ratio of the ablation pit produced during a $60 \mathrm{~s}$ ablation was significantly less than one. Masses 204, 206 and 207 were measured in secondary electron multipliers, and 238 in the extra high mass Faraday collector of the $\mathrm{Nu}$ Plasma U-Pb collector block. The geometry of the collector block does not allow simultaneous measurement of ${ }^{208} \mathrm{~Pb}$ and ${ }^{232} \mathrm{Th}$.

Ion counter counts were converted and reported as volts by the Nu Plasma time-resolved analysis software. ${ }^{235} \mathrm{U}$ was calculated from the signal at mass 238 using a natural ${ }^{238} \mathrm{U} /{ }^{235} \mathrm{U}=137.88$.

Mass number 204 was used as a monitor for common ${ }^{204} \mathrm{~Pb}$. In an ICPMS analysis, ${ }^{204} \mathrm{Hg}$ originating from the argon supply contaminates mass 204, the observed background counting-rate was ca. $1000 \mathrm{cps}\left(\sim 1.6 \times 10^{-5} \mathrm{~V}\right)$, and has been stable at that level over a three-year period. The contribution of ${ }^{204} \mathrm{Hg}$ from the plasma was eliminated by on-mass background measurement prior to each analysis. At the low laser energy used, there was no excess ionization of ${ }^{204} \mathrm{Hg}$ from the gas supply during ablation, so that the on-mass background measurement is representative for the conditions during analysis. Analyses which yielded peak/background ratios at mass 204 of less than $1+3 \operatorname{RSD}_{\mathrm{B}}$ (where $\mathrm{RSD}_{\mathrm{B}}$ is the observed relative standard deviation of the onpeak background measurement), were considered to have common lead below the detection limit. Typically, this amounts to a background-corrected signal strength on mass 204 of $\sim 1.5 \times 10^{-6} \mathrm{~V}$. For comparison, standards 91500 and GJ-1, which are known to contain negligible amounts of common lead (Wiedenbeck et al., 1995; Jackson et al., 2004) gave back-ground corrected signal strengths $<1.0 \times 10^{-6} \mathrm{~V}$, i.e. well below the detection limit. In the present study, samples showing common lead contents above the detection limit were discarded. In contrast, background levels at masses 206 and 207, which are not influenced by isobaric overlap from contaminating nuclides are $\leqslant 300 \mathrm{cps}$ $\left(\leqslant 5 \times 10^{-6} \mathrm{~V}\right)$. Signal strengths on mass 206 for Phanerozoic zircons were typically $>(>)$
$10^{-4} \mathrm{~V}$, depending on the uranium content of the zircons.

One or two calibration standards were run in duplicate at the beginning and end of each analytical session, and at regular intervals during sessions. Raw data from the mass spectrometer (converted to volts) were corrected for background, laser-induced elemental fractionation, mass discrimination and drift in ion counter gains and reduced to $\mathrm{U}$ and ${ }^{206} \mathrm{~Pb}$ concentrations and $\mathrm{U}-\mathrm{Pb}$ isotope ratios by calibration to concordant reference zircons of known age, using protocols adapted from Andersen et al. (2004) and Jackson et al. (2004). Standard zircons GJ-01 (609 $\pm 1 \mathrm{Ma}$; Belousova et al. 2006) and 91500 (1065 \pm 1 Ma; Wiedenbeck et al. 1995) were used for calibration. The calculations were done off-line, using an in-house interactive spreadsheet program written in Microsoft $\mathrm{Excel}^{\mathrm{TM}} / \mathrm{VBA}$, but with the most computationheavy routines written in $\mathrm{C}$ for greater speed of calculation.

Background-corrected signals for mass numbers 204, 206, 207 and 238 and the ${ }^{207} \mathrm{~Pb} /{ }^{206} \mathrm{~Pb},{ }^{206} \mathrm{~Pb} /{ }^{238} \mathrm{U}$ and ${ }^{207} \mathrm{~Pb} /{ }^{235} \mathrm{U}$ isotope ratios were plotted as traces of observed voltage and voltage ratios against ablation time, and timeintervals which were homogeneous in isotopic composition were selected interactively for integration. To minimize the effects of laserinduced elemental fractionation, the depth-todiameter ratio of the ablation pit was kept low, and isotopically homogeneous segments of the time-resolved traces were calibrated against the corresponding time interval for each mass in the reference zircon. To compensate for drift in instrument sensitivity and Faraday vs. electron multiplier gain during an analytical session, a linear correlation of signal vs. time was assumed for the reference zircons.

The calibration software incorporates two different algorithms for the conversion of background- and drift-corrected signal ratios to isotope and element ratios. The simplest approach assumes that the isotopic ratio is a linear function of signal ratio and time, i.e.

$$
y=x(\mathrm{a}+\mathrm{c} t) \overline{\bar{\equiv}}
$$

where $y$ is the isotopic ratio to be determined, $x$ is the observed voltage ratio and $t$ the time since the start of the analytical session. The coefficients and $\equiv$ determined by linear regression of th $\overline{\overline{\bar{\nu}}}$ calill $\overline{\bar{\nu}}$ standards. This approach is equivalent to that incorporated in the commercial software 
package GLITTER (van Achterberg et al., 2000). One or more standards can be used to determine $a$ and $c$ by linear regression. At high counting rates on the ion counters (typically $>100000 \mathrm{cps}$ ), effects of deadtime and deviations from detector linearity affect the results. This can be compensated by introducing a second-order term in the calibration equation:

$$
y=x(\mathrm{a}+\mathrm{b} x+\mathrm{c} t) \equiv
$$

The coefficients $\mathrm{a}, \mathrm{b}$ and $\mathrm{c}$ are determined by regression of data from two or more reference samples. The non-linear calibration is mainly relevant for zircons with elevated ${ }^{206} \mathrm{~Pb} /{ }^{238} \mathrm{U}$ ratio, i.e. mid-Proterozoic or older zircons. For the Phanerozoic zircons analysed in the present study, counting rates are much lower, and equations 1 and 2 give indistinguishable results (Table $\mathrm{A} 1)$. $\mathrm{U}$ and ${ }^{206} \mathrm{~Pb}$ concentrations were calculated from observed signals at masses 238 and 206, calibrated to standards according to equation 1 .

The estimated uncertainties in isotope ratios incorporate error terms from counting statistics on signals and backgrounds for the relevant masses measured on standards and unknowns, the standard error of the regression line determined from standards, and the published uncertainty of the calibration standards. The terms have been propagated through, using standard error propagation algorithms (e.g. Taylor, 1997). The correlation coefficient of errors in the ${ }^{206} \mathrm{~Pb} /{ }^{238} \mathrm{U}$ and ${ }^{207} \mathrm{~Pb} /{ }^{235} \mathrm{U}\left(=137.88 \cdot{ }^{.207} \mathrm{~Pb} /{ }^{238} \mathrm{U}\right)$ ratios has been determined from the raw data for each analysis.

The Phanerozoic Temora-2 (TIMS-ID U-Pb age: $416.8 \pm 1.3 \mathrm{Ma}$; Black et al., 2004) and Plešovice (TIMS-ID U-Pb age: $337.1 \pm 0.4 \mathrm{Ma}$; Sláma et al., 2008) reference zircons were run as unknowns; data obtained during this study are given in Table $\mathrm{A} 1_{\wedge}$ and Fig. $\mathrm{A} 1$.

\section{Petrography}

The chloritized granular felsic to intermediate rock is medium-grained, holocrystalline and equigranular. Its texture is intergranular, with anhedral quartz, plagioclase and K-feldspar grains. Some samples contain hornblende, which is commonly chloritized. Accessory apatite needles are ubiquitous. The granular felsic lithology is also a medium-grained holocrystalline equigranular rock. However, hornblende is absent and alteration to chlorite is therefore scarce. In addition, quartz and feldspar occasionally display granophyric intergrowths. The quartz-feldsparphyric porphyry contains large $(<4 \mathrm{~mm})$ quartz and, in smaller amounts, feldspar and plagioclase phenocrysts in a microfelsitic groundmass. These quartz phenocrysts are occasionally euhedral, but frequently display resorption embayments and reaction rims.

Cathodoluminescence images reveal that the quartz of these rocks has a weak blue luminescence, without evidence of zoning. This suggests a relatively simple crystallization history during quartz growth, without abrupt variations in magma composition and/or temperature.

Accessory amounts of zircon are present in the three rock types, as prismatic crystals, $\sim 100$ ìm long. The CL of these crystals exhibits complex oscillatory zoning patterns, providing evidence for multistage growth histories, with possible inherited cores. The morphological study of the zircon grains, based on the recognition of the crystal forms on CL images, using the method of Belousova et al. (2006), shows that most zircons from the Azinhalinho volcanic rocks have a developed $\{110\}$ prism and both $\{101\}$ and $\{211\}$ pyramids, with the former being generally better developed. These zircons therefore correspond to subtypes S8 and/or S9 of Pupin's (1980) typological classification. These morphological features are typical of zircons from low-temperature aluminous rocks, of mainly crustal origin. In some grains, the zoning suggests that the zircon morphology, with a well developed $\{110\}$ prism and with $\{211\}$ as the predominant pyramid, constitutes overgrowths on zircon with $\{100\}$ prism or with similar amounts of the two pyramids, corresponding to subtypes S22 and/or S23 (Fig. 2). This would suggest that zircon crystallized while the magma cooled and became slightly more alkaline.

All rock types contain accessory amounts of goethite pseudomorphs after pyrite. Some samples retain trace amounts of pyrite and/or chalcopyrite.

\section{Lithogeochemistry}

Lithogeochemistry data for the more relevant elements are presented in Table 1. On immobile elemental plots, using $\mathrm{Al}, \mathrm{Zr}$ and $\mathrm{Ti}$, for example, the three different rock types plot along distinct alteration lines that converge towards the origin, reflecting elemental covariation, despite some possible fractionation effects. The chloritized granular felsic to intermediate rock has 

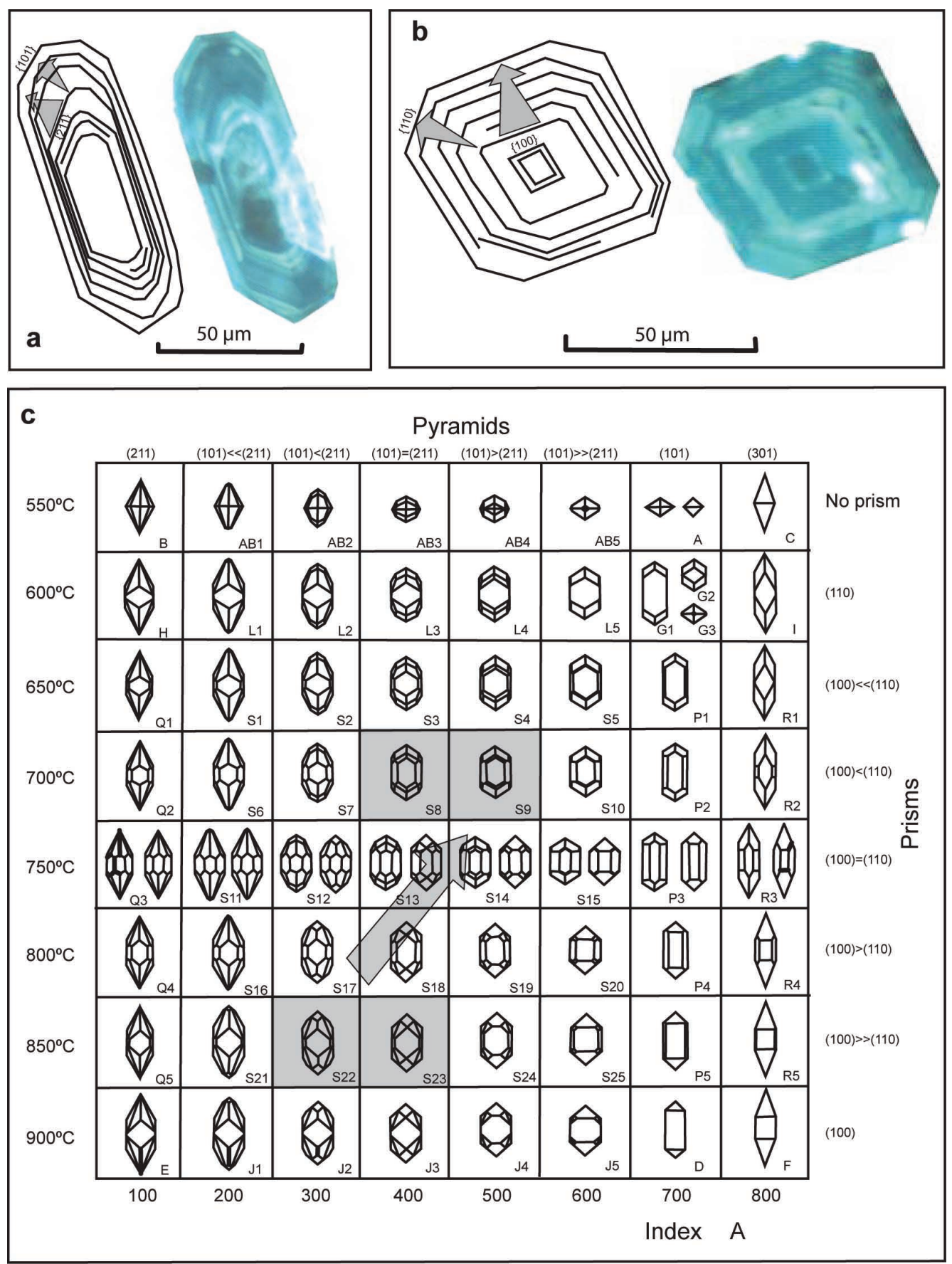

FIG. 2. Morphological types of zircon from a quartz-feldspar-phyric porphyryry from Azinhalinho (sample VA17), as evidenced through CL imaging, and established trend on the typological classification scheme of Pupin (1980): (a) illustration of the progression of pyramids; $(b)$ illustration of the change of prisms; $(c)$ trend on the typological scheme. The images were acquired under the following instrumental settings: accelerating potential of $14 \mathrm{kV}$ and probe current of $600 \mu \mathrm{A}$. 


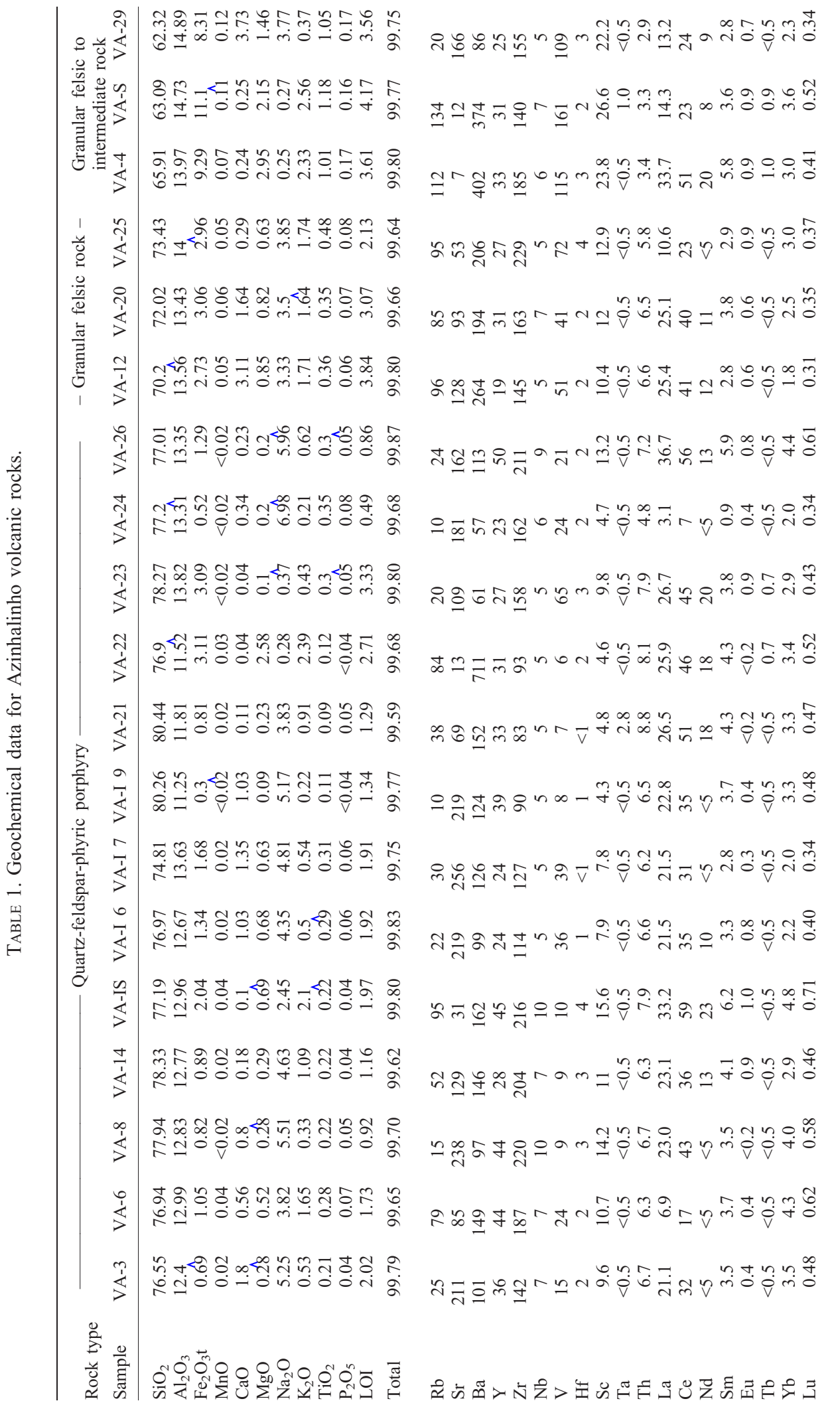




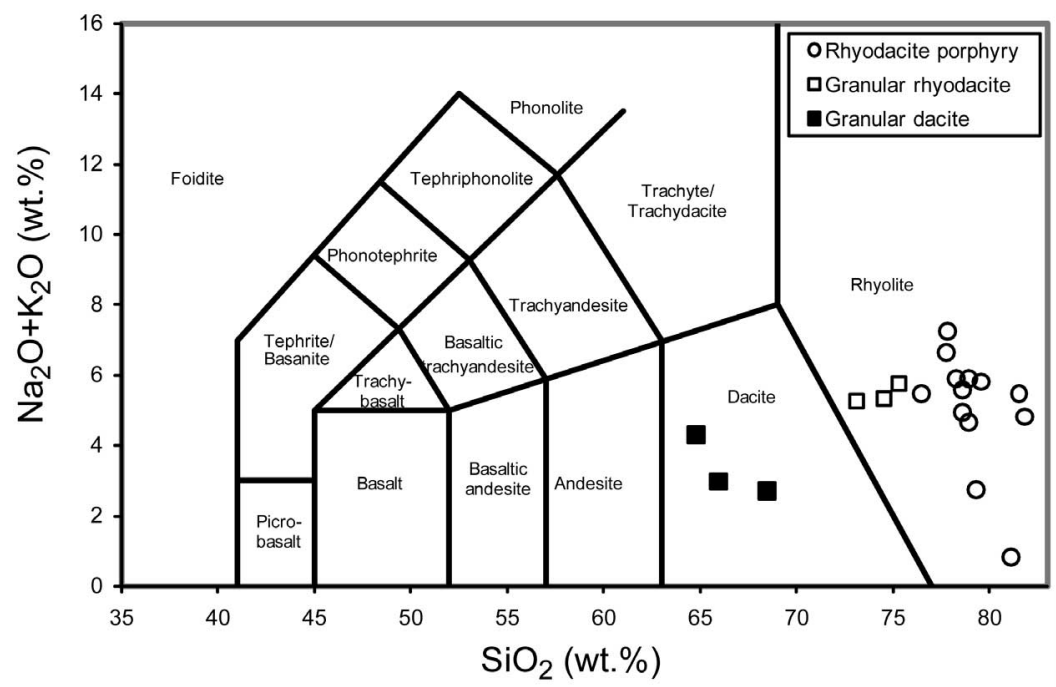

FIG. 3. Plot of Azinhalinho volcanic rocks on the TAS diagram of Le Maitre et al. (1989).

$\mathrm{Al}_{2} \mathrm{O}_{3} / \mathrm{TiO}_{2} \approx 15$ and $\mathrm{Zr} / \mathrm{TiO}_{2} \approx 150$, while the granular felsic rock has $\mathrm{Al}_{2} \mathrm{O}_{3} / \mathrm{TiO}_{2} \approx 30$ and $\mathrm{Zr} / \mathrm{TiO}_{2} \approx 400$ and the quartz-feldspar-phyric porphyry has $\mathrm{Al}_{2} \mathrm{O}_{3} / \mathrm{TiO}_{2} \approx 40$ and $\mathrm{Zr} / \mathrm{TiO}_{2} \approx$ 600 .

On the TAS diagram of Le Maitre et al. (1989), the granular felsic rock samples plot within the rhyolite field, but towards the dacite end (Fig. 3). The quartz-feldspar-phyric porphyry samples plot clearly within rhyolite. However, considering the mobile nature of the elements used on this diagram, these results should be treated with caution. To avoid the problems with mobility of major elements, a diagram using immobile elements can be used. In the Winchester and Floyd (1977) diagram, the porphyry and the granular felsic samples plot in the rhyodacite/ dacite fields (Fig. 4). In this case, the classification of these rocks on the TAS diagram, discussed above, partially reflects silicification processes previously described in IPB rocks (Rosa et al, 2004).

The chloritized granular felsic to intermediate rock plots on the dacite field of the TAS diagram

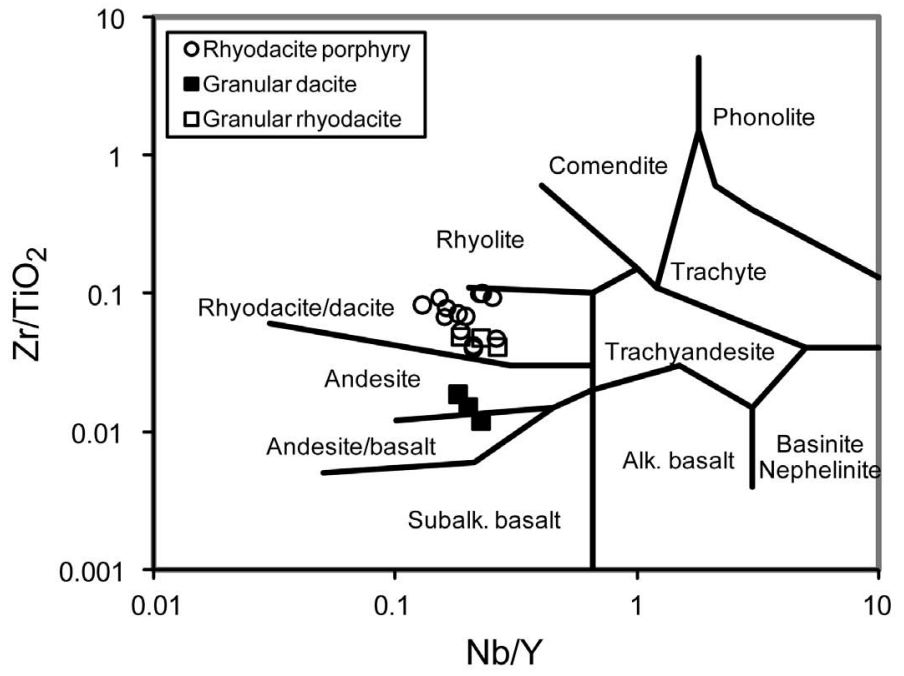

FIG. 4. Plot of the Azinhalinho volcanic rocks on the Winchester and Floyd (1977) diagram. 
(Fig. 3), compatible with the presence of hornblende in thin section. However, on the Winchester and Floyd (1977) diagram, these rocks plot between the andesite and andesite/ basalt fields (Fig. 4). This is in stark contrast with the petrography and is interpreted to be the result of anomalously high $\mathrm{Ti}$ concentrations, coupled with anomalously low $\mathrm{Zr}$ concentrations caused by the low-temperature crustal fusion that generated the magma that yielded this rock type. Rosa et al. (2004) reported on similar classification problems with felsic rocks from Albernoa, $<5 \mathrm{~km}$ to the South of Azinhalinho, but within the IPB. Elsewhere, this type of problem has been reported by Piercey et al. (2001) and Lentz (1999) for felsic rocks from the Finlayson Lake District, Yukon, and Bathurst, New Brunswick, respectively.

\section{Geochronology}

$\mathrm{The} \mathrm{U}-\mathrm{Pb}$ analytical results, for zircon grains from three samples of volcanic rocks, are compiled in Table $2_{\kappa}$ Concordia ages were calculated using ISOPLOT version 3 (Ludwig, 2003), with errors reported at the $95 \%( \pm 2 \sigma)$ confidence level.

The best estimate of the crystallization age of sample VA12, a granular rhyodacite, is $356 \pm 1.4 \mathrm{Ma}$, based upon the analyses of twentysix concordant zircon grains (Fig. 5). Sample
VA15, of rhyodacite porphyry, yielded thirteen zircon grains, most of them plotting slightly off the concordia line, probably because of some common lead contamination (Fig. 6). The clear and euhedral zircon grains provide a timing for the emplacement of this sample at $355 \pm 2.5 \mathrm{Ma}$. Another rhyodacite porphyry sample, VA 16, yielded nineteen concordant zircon grains, providing an age of $356 \pm 1.5 \mathrm{Ma}$ (Fig. 7).

In addition to the discussed magmatic zircon grains, six grains from VA12 and one from VA16 indicate a Neo-proterozoic inheritance (Fig. 8).

\section{Discussion}

When plotted on the tectonic discrimination diagrams of Pearce et al. (1984), the Azinhalinho rhyodacites and dacites display volcanic arc signatures (Fig. 9). It is possible that the low temperature of crustal fusion affects the HFSE concentrations and renders these diagrams inappropriate, as documented above for the Winchester and Floyd (1977) diagram. In fact, if HFSE concentrations were higher, possibly as a result of crustal fusion at higher temperatures, the Azinhalinho rocks would plot in the withinplate field. This misclassification has also been reported for IPB rocks (Rosa et al., 2004; 2006), for which a strike-slip tectonic model imposed by

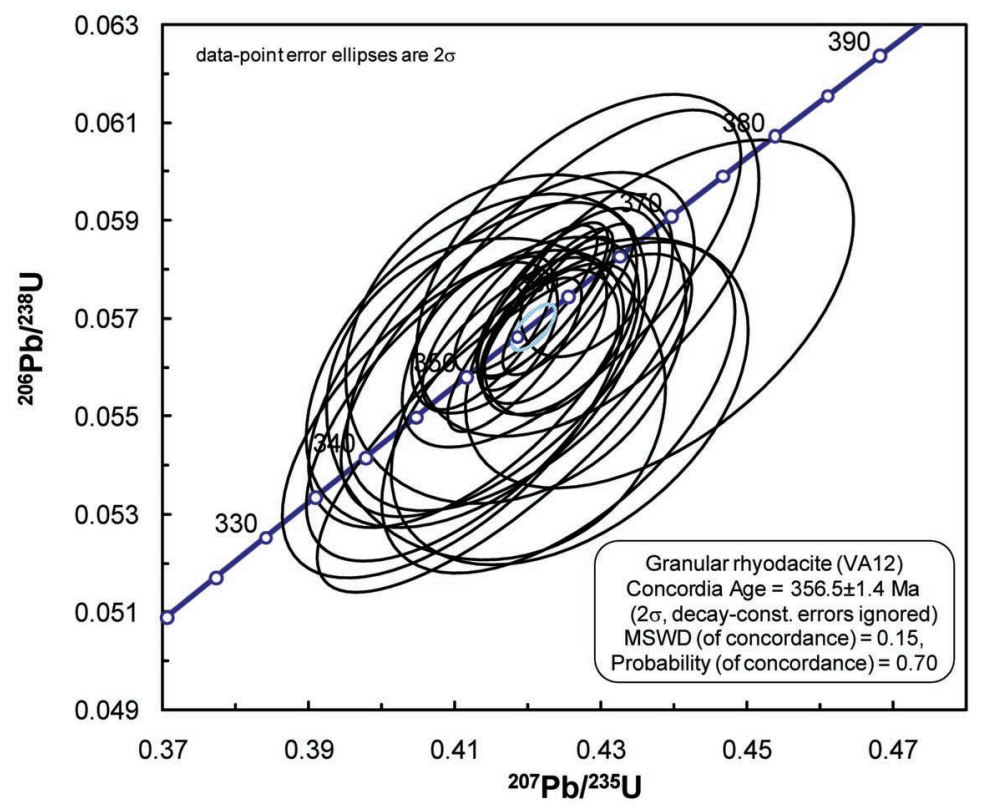

FIG. 5. Concordia diagram for the rhyodacite porphyry (sample VA12). Twenty-six analyses, each corresponding to a different zircon grain. 
D. R. N. ROSA ET AL.

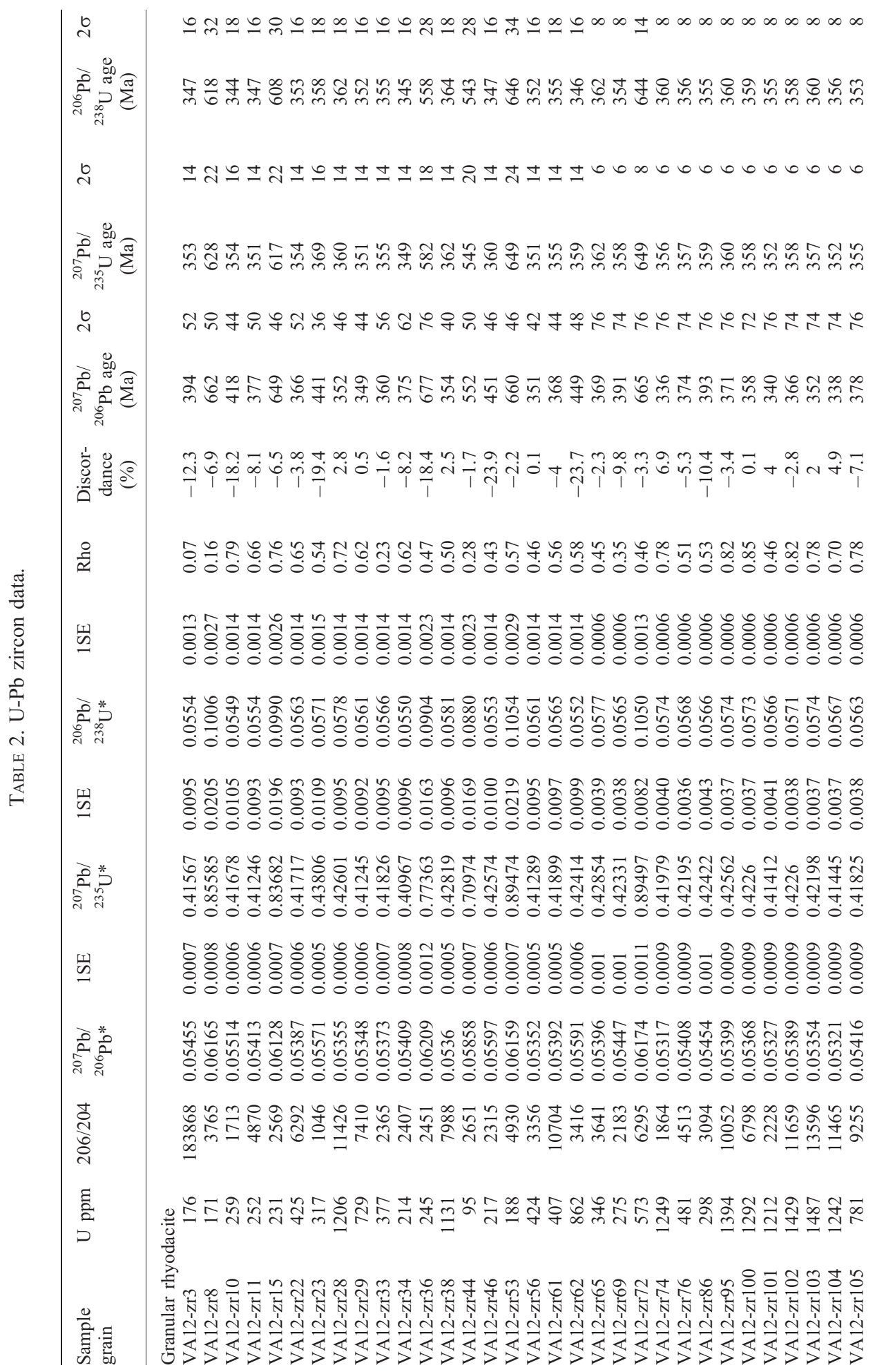


$\infty \infty \infty \infty \infty \infty \infty \infty \infty \infty \infty$

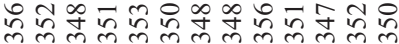

$\infty \vee \infty \infty \infty \vee \sigma \infty \infty \infty \infty \infty \infty$

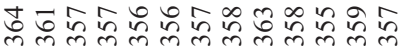

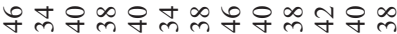

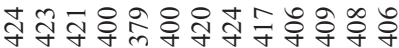

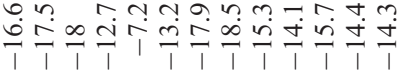

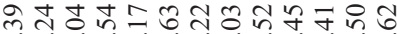

0.00000000000

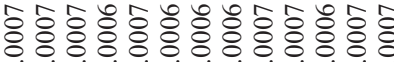

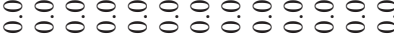

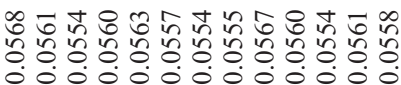

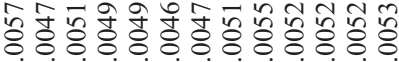
0000000000000

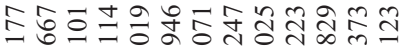

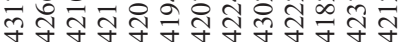

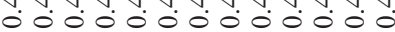

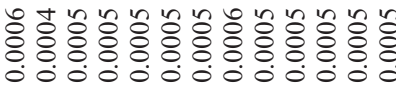

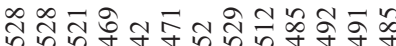

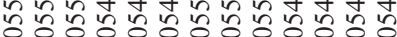
0000000000000

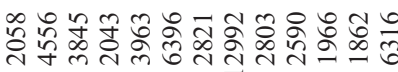

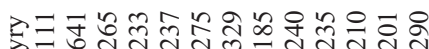
롱

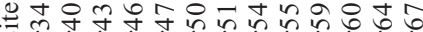

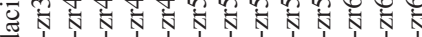

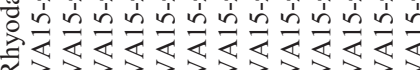

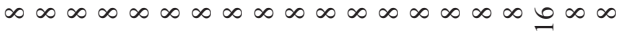

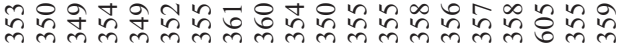

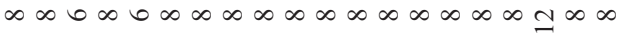

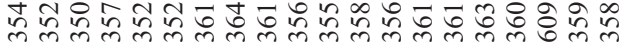

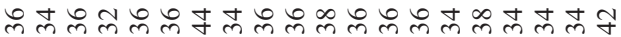

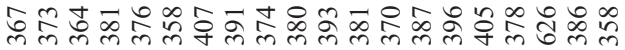

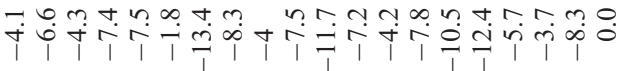

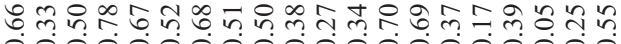
00000000000000000000

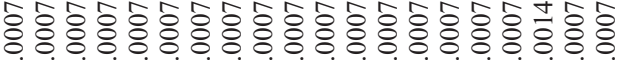

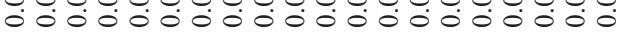

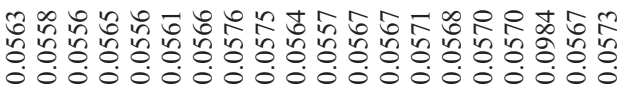

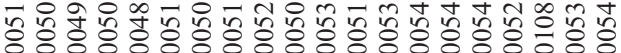

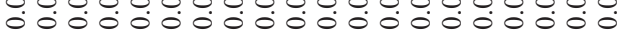

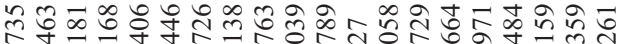

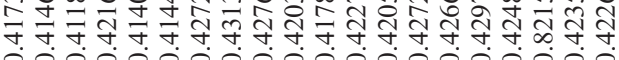

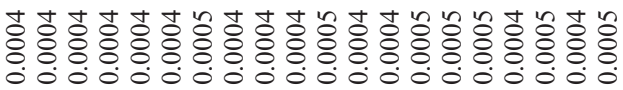

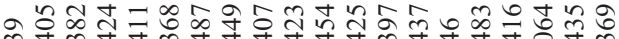

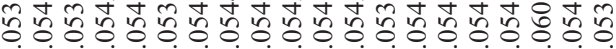

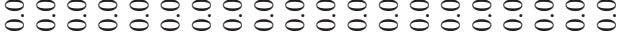

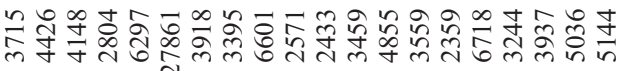

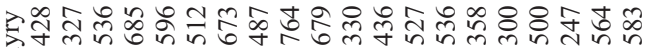
를

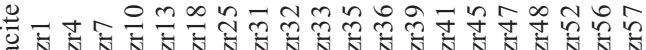

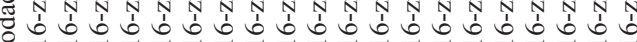

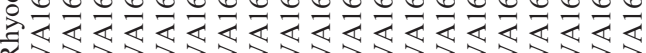




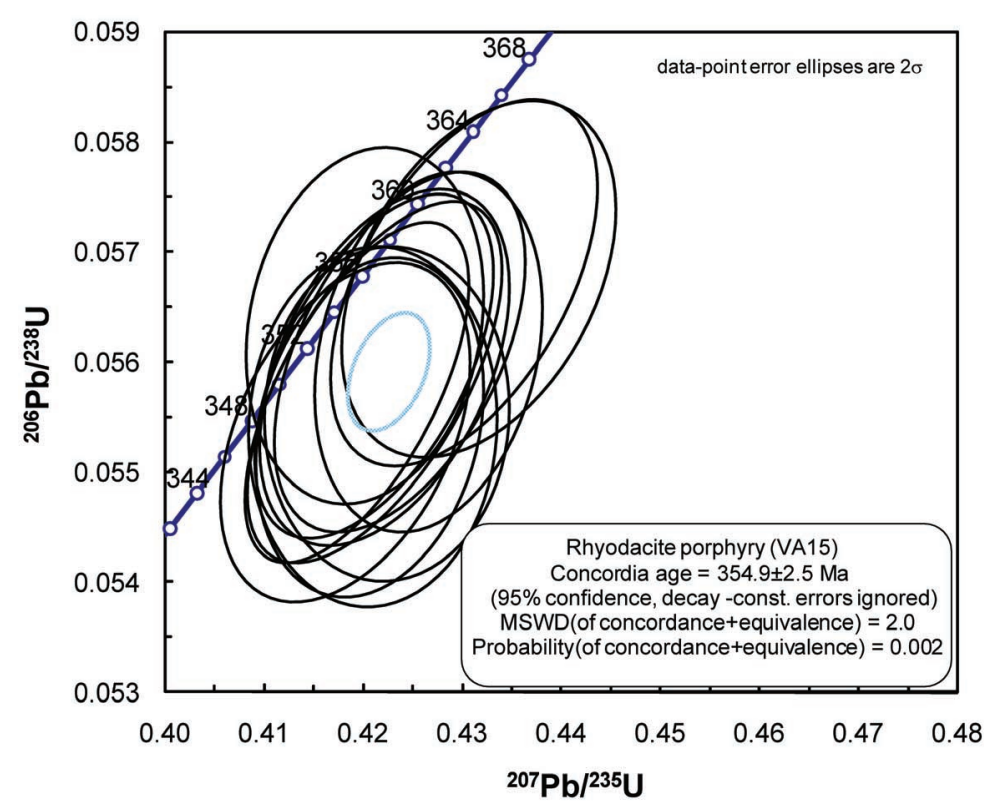

FIG. 6. Concordia diagram for the granular dacite (sample VA15). Thirteen analyses, each corresponding to a different zircon grain.

oblique subduction is proposed by Silva et al. (1990) and Quesada (1991), compatible with a within-plate geochemical signature.
It is apparent then, from the geochemical data, that the Azinhalinho rocks can be compared to felsic rocks from the IPB. The granular rhyodacite

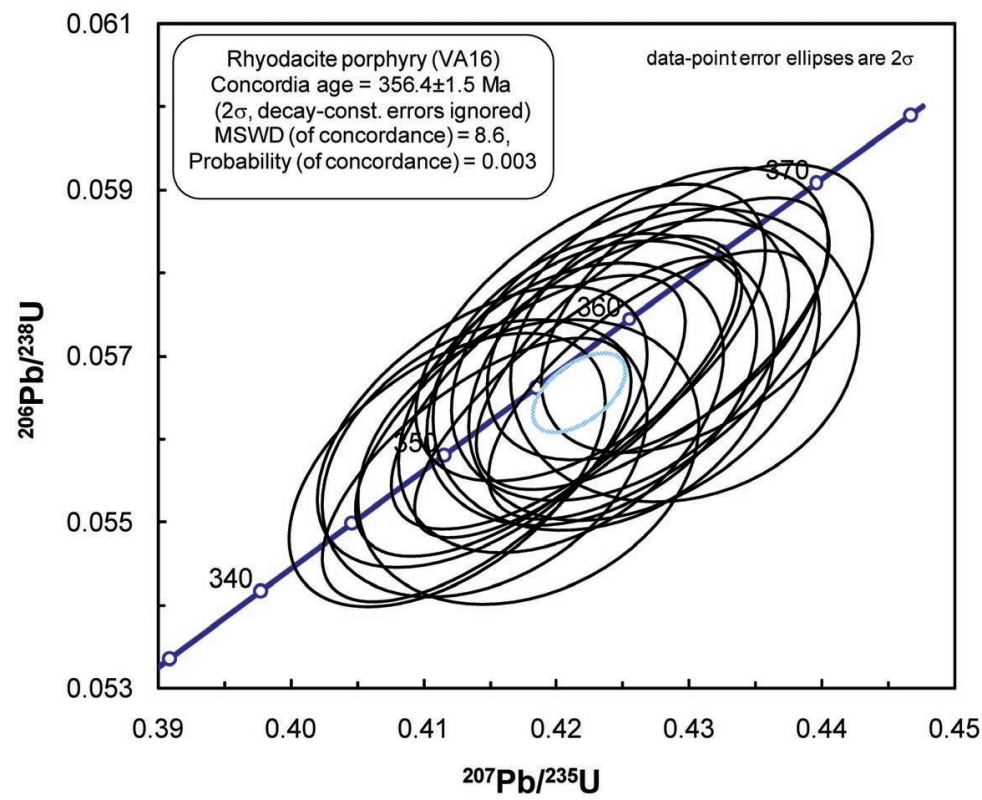

FIG. 7. Concordia diagram for the granular rhyodacite (sample VA16). Nineteen analyses, each corresponding to a different zircon grain. 


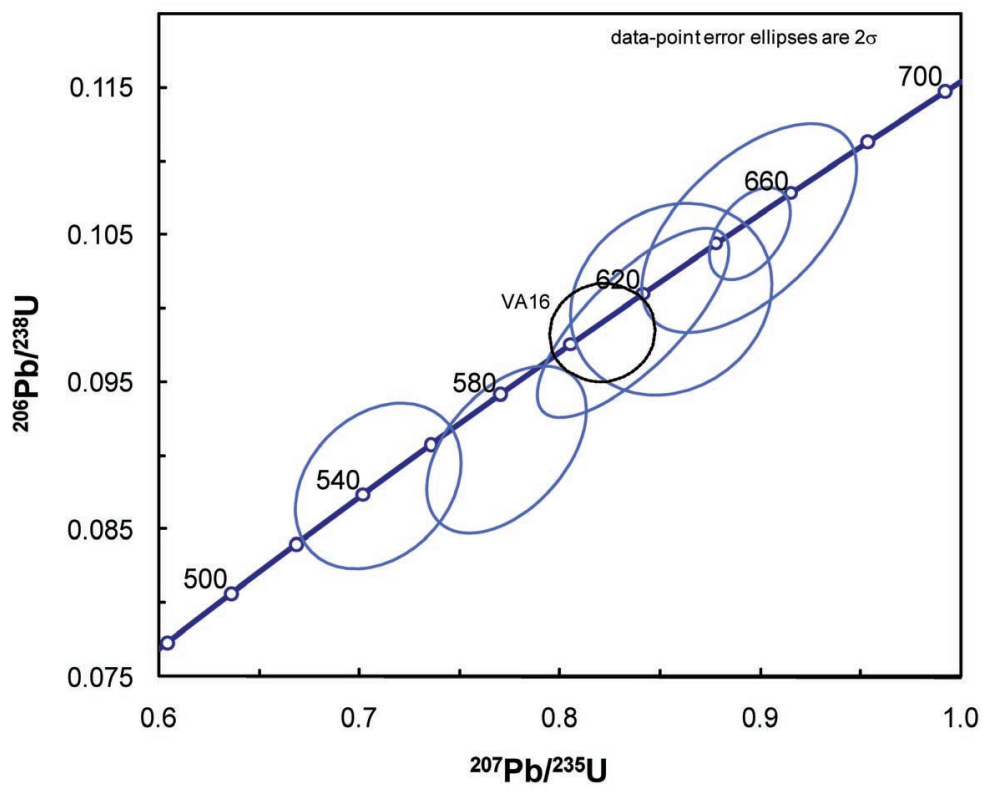

FIG. 8. Inherited zircon grains (six grains from VA12 and one grain, with dashed error ellipse, from VA16).

and the rhyodacite porphyry can be compared with felsic rocks from Serra Branca (Rosa et al., 2006). These rocks have HFSE concentrations that provide relatively consistent results in the Winchester \& Floyd (1977) diagram. However, the temperature of crustal fusion may have not been high enough to cause complete melting of the refractory phases in which HFSE reside and therefore they provide confusing results on the tectonic discrimination diagrams of Pearce et al.

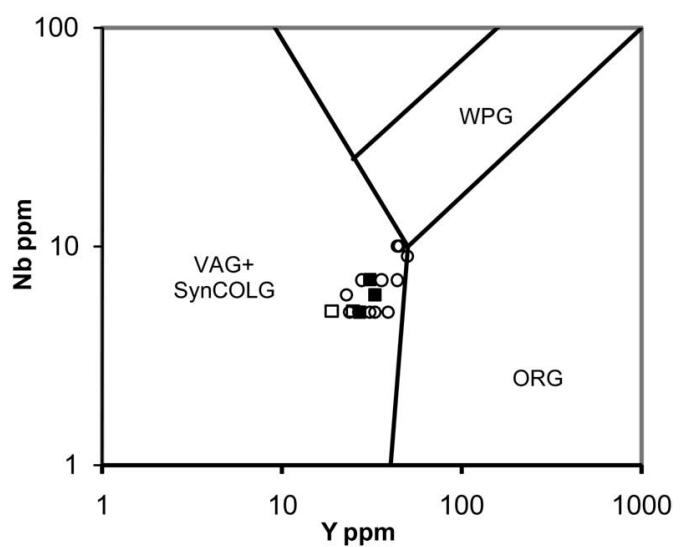

Fig. 9. Plot of the Azinhalinho volcanic rocks on the tectonic discrimination diagram of Pearce et al. (1984). Same symbols as in Figs 3 and 4.
(1984). The Azinhalinho granular dacite corresponds to a less evolved equivalent of the rhyodacites present in Albernoa (Rosa et al., 2004), just a few km to the South, with both rock types displaying characteristic anomalously low $\mathrm{Zr}$ and other HFSE concentrations. These anomalous characteristics clearly affect their classification on the Pearce et al. (1984) and Winchester and Floyd (1977) fields.

Biostratigraphic research, based on palynomorph data indicates that the Gafo Formation belongs to the BM Biozone of Frasnian age (Oliveira et al., 2006; Pereira et al., 2006). Therefore, the Gafo Formation was deposited between 385.3 and 374.5 Ma (Gradstein et al, 2004), synchronously with Phyllite-Quartzite Group sedimentation in the IPB basin. This is in contrast with the statistically identical radiometric ages reported here, assigning Tournaisian ages for the Azinhalinho volcanic rocks. In this case, the radiometric ages obtained suggest that the Azinhalinho volcanic rocks are intrusive in the older Frasnian Gafo Formation.

Considering that the IPB volcanism extends from the Famennian to the Visean (Dunning et al., 2002; Barrie et al., 2002; Rosa et al., 2008), one can conclude that the Azinhalinho volcanism, in addition to being geochemically similar, was synchronous with IPB volcanism. The 
Azinhalinho volcanic rocks can therefore be interpreted as feeders that cut across older rocks to generate the IPB volcanism stratigraphically above.

\section{Conclusions}

Based on the similar geochemical signatures of the volcanic rocks from Azinhalinho and the volcanic rocks from the IPB, we consider that the Azinhalinho volcanism was formed in a setting similar to that of the IPB volcanism, i.e. withinplate volcanism resulting from oblique collision. A Neo-Proterozoic component was present in the zircons during formation of Azinhalinho magmas, as indicated by inherited zircon grains present in some volcanic rock samples. This is consistent with derivation of magmas by partial melting of crust, which is further supported by the morphological features of the igneous zircon, and is similar to what has been proposed for IPB magmas.

Radiometric data show that the Azinhalinho volcanism was marked by the emplacement of rhyodacite porphyry and granular rhyodacite, at ca. $356 \mathrm{Ma}$ (Tournaisian). These data confirm that the Azinhalinho and IPB volcanisms were broadly contemporaneous. Since Azinhalinho volcanic rocks are hosted in older Frasnian Gafo Formation, this volcanism must have had an intrusive nature, likely corresponding to feeders to IPB volcanic rocks.

\section{Acknowledgements}

This work was sponsored by an International Incoming Short Visits grant from the Royal Society, by an EFTA Grant and by the POCTI program of the Fundação para a Ciência e Tecnologia (Portugal). The authors would like to acknowledge Donald Herd (University of St Andrews) and Berit Løken Berg and Gunborg Bye-Fjeld (University of Oslo) for their assistance with sample preparation and characterization and Siri Simonsen (University of Oslo) for her assistance during LA-ICPMS work. Further laboratory support was provided by M.E.D. Moreira from the INETI laboratory (Porto, Portugal) and by the CREMINER-Centro de Recursos Minerais, Mineralogia e Cristalografia, at the University of Lisbon. This is publication no. 5 from the Department of Geosciences, University of Oslo ICPMS laboratory. The authors are also grateful to Elena Belousova and
Adrian Brearley for their detailed and constructive reviews that significantly improved the paper.

\section{References}

Andersen, T., Graham, S. and Sylvester, A.G. (2007) Timing and tectonic significance of Sveconorwegian A-type granitic magmatism in Telemark, southern Norway: New results from laser-ablation ICPMS U$\mathrm{Pb}$ dating of zircon. Norges geologiske underskelse, 447, 17-31.

Andersen, T., Griffin, W.L., Jackson, S.E., Knudsen, T.L. and Pearson, N.J. (2004) Mid-Proterozoic magmatic arc evolution at the southwest margin of the Baltic Shield. Lithos, 73, 289-318.

Barrie, C.T., Amelin, Y. and Pascual, E. (2002) U-Pb geochronology of VMS mineralization in the Iberian Pyrite Belt. Mineralium Deposita, 37, 684-703.

Belousova, E.A., Griffin, W.L. and O'Reilly, S.Y. (2006) Zircon crystal morphology, trace element signatures and $\mathrm{Hf}$ isotope composition as a tool for petrogenetic modeling: examples from Eastern Australian granitoids. Journal of Petrology, 47, 329-353.

Black, L.P., Kamo, S.L., Allen, C.M., Davis, D.W., Aleinikoff, J.N., Valley, J.W., Mundil, R., Campbell, I.H., Korscha, R.J., Williams, I.S. and Foudoulis, C. (2004) Improved ${ }^{206} \mathrm{~Pb} /{ }^{238} \mathrm{U}$ microprobe geochronology by the monitoring of a trace-element-related matrix effect; SHRIMP, ID-TIMS, ELA-ICP-MS and oxygen isotope documentation for a series of zircon standards. Chemical Geology, 205, 115-140.

Dunning, G.R., Diez Montes, A., Matas, J., Martin Parra, L.M., Almarza, J. and Donaire, M. (2002) Geocronología $\mathrm{U} / \mathrm{Pb}$ del volcanismo ácido y granitoides de la Faja Pirítica Ibérica (Zona Surportuguesa). Geogaceta, 32, 127-130.

Gradstein, F.M., Ogg, J.G. and Smith, A.G. (2004) A Geologic Time Scale. Cambridge University Press, Cambridge, UK, 610pp.

Jackson, S.E., Pearson, N.J., Griffin, W.L. and Belousova, E.A. (2004) The application of laser ablation-inductively coupled plasma-mass spectrometry to in-situ U-Pb zircon geochronology. Chemical Geology, 211, 47-69.

Julivert, M., Fontbote, J.M., Ribeiro, A. and Conde, L. (1972) Mapa tectónico de la Península Ibérica y Baleares, 1/1.000.000. Instituto Geológico Minero de España.

Le Maitre, R.W., Bateman, P., Dudek, A., Keller, J., Lameyre, J., Le Bas, M.J., Sabine, P.A., Schmid, R., Sørensen, H., Streckeisen, A., Woolley, A.R. and Zanettin, B. (editors) (1989) A classification of igneous rocks and glossary of terms. Blackwell, Oxford, UK, $193 \mathrm{pp}$.

Lentz, D.R. (1999) Petrology, geochemistry, and oxygen 
isotope interpretation of felsic volcanic and related rocks hosting the Brunswick 6 and 12 massive sulfide deposits (Brunswick Belt), Bathurst Mining camp, New Brunswick, Canada. Economic Geology, 94, 57-86.

Ludwig, K.R. (2003) ISOPLOT 3.0 - A Geochronological Toolkit for Microsoft Excel ${ }^{\mathrm{TM}}$. Berkeley Geochronology Center Special Publication, 4, $70 \mathrm{pp}$.

Munhá, J. (1990) Metamorphic evolution of the South Portuguese/Pulo do Lobo Zone. Pp. 363-368 in: Pre-Mesozoic Geology of Iberia (R.D. Dallmeyer and E. Martinez Garcia, editors). Springer-Verlag, Berlin Heidelberg New York.

Oliveira, J.T. (editor) (1988), Notícia Explicativa da Folha 8, Carta Geológica de Portugal 1/200.000: Serviços Geológicos Portugal, 91 pp.

Oliveira, J.T., Relvas, J.M.R.S., Pereira, Z., Matos, J.X., Rosa, C.J., Rosa, D., Munhá, J.M., Jorge, R.C.G.S. and Pinto, A.M.M. (2006) O Complexo vulcanosedimentar da Faixa Piritosa: Estratigrafia, vulcanismo, mineralizações associadas e evolução tectonoestratigráfica no contexto da Zona Sul-Portuguesa. Pp. 207-243 in: Geologia de Portugal no contexto da Ibéria (R. Dias, A. Araújo, P. Terrinha and J.C. Kullberg, editors). Universidade de Évora, Évora, Portugal.

Pearce, J.A., Harris, N.B.W. and Tindle, A.G. (1984) Trace element discrimination diagrams for the tectonic interpretation of granitic rocks. Journal of Petrology, 25, 956-983.

Pereira, Z., Fernandes, P. and Oliveira, J.T. (2006) Palynostratigraphy of the Pulo do Lobo Domain, South Portuguese Zone. Pp. 649-652 in: Proceedings of the VII Portuguese Geological Congress, Évora, Portugal.

Piercey, S.J., Pardais, S., Murphy, D.C. and Mortensen, J.K. (2001) Geochemistry and paleotectonic setting of felsic volcanic rocks in the Finlayson Lake volcanic-hosted massive sulfide district, Yukon, Canada. Economic Geology, 96, 1877-1906.

Pupin, J.P. (1980) Zircon and granite petrology. Contributions to Mineralogy and Petrology, 73, 207-220.

Quesada, C. (1991) Geological constraints on the Paleozoic tectonic evolution of tectonostratigraphic terranes in the Iberian massif. Tectonophysics, $\mathbf{1 8 5}$, 225-245.

Røhr, T.S., Andersen, T. and Dypvik, H. (2008) Provenance of Lower Cretaceous sediments in the Wandel Sea Basin, North Greenland. Journal of the Geological Society, 165, 755-767.
Rosa, D.R.N., Inverno, C.M.C., Oliveira, V. and Rosa, C. (2004) Geochemistry of volcanic rocks, Albernoa area, Iberian Pyrite Belt, Portugal. International Geology Review, 46, 366-383.

Rosa, D.R.N., Inverno, C.M.C., Oliveira, V. and Rosa, C. (2006) Geochemistry and geothermometry of volcanic rocks from Serra Branca, Iberian Pyrite Belt, Portugal. Gondwana Research, 10, 328-339.

Rosa, D.R.N., Finch, A.A., Andersen, T. and Inverno, C.M.C. (2008) U-Pb geochronology and Hf isotope ratios of magmatic zircons from the Iberian Pyrite Belt. Mineralogy and Petrology, 95, (DOI: 10.1007 s00710-008-0022-5)

Silva, J.B., Oliveira, J.T. and Ribeiro, A. (1990) South Portuguese Zone. Structural outline. Pp. 348-362 in: Pre-Mesozoic geology of Iberia (R.D. Dallmeyer and E. Martinez Garcia, editors). Springer-Verlag, Berlin Heidelberg New York.

Simonetti, A., Heaman, L.M., Hartlaub, R.P., Creaser, R.A., MacHattie, T.G. and Böhm, C. (2005) U-Pb zircon dating by laser ablation-MC-ICP-MS using a new multiple ion counting Faraday collector array. Journal of Analytical Atomic Spectrometry, 20, 677-686.

Sláma, J., Košler, J., Condon, D.J., Crowley, J.L., Gerdes, A., Hanchar, J.M., Horstwood, M.S.A., Morris, G.A., Nasdala, L., Norberg, N., Schaltegger, U., Schoene, B., Tubrett, M.N. and Whitehouse, M.J. (2008) Plešovice zircon - A new natural reference material for $\mathrm{UPb}$ and $\mathrm{Hf}$ isotopic microanalysis. Chemical Geology, 249, 1-35.

Taylor, J.R. (1997) An Introduction to Error Analysis: The Study of Uncertainties in Physical Measurements, 2nd. edition. University Science Books, Sausalito, CA,USA, 327pp.

van Achterbergh, E., Ryan, C.G., Jackson, S.E. and Griffin, W.L. (2000) Data Reduction software for LA-ICPMS: Appendix. Pp. 239-243 in: Laser Ablation-ICP-Mass Spectrometry in the Earth Sciences: Principles and Applications (P.J. Sylvester, editor). Mineralogical Association of Canada Short Course Series, 29.

Wiedenbeck, M., Alle, P., Corfu, F., Griffin, W.L., Meier, M., Oberli, F., Von Quadt, A., Roddick, J.C. and Spiegel, W. (1995) Three natural zircon standards for U-Th-Pb, Lu-Hf, trace element and REE analyses. Geostandards Newsletter, 19, 1-23.

Winchester, J.A. and Floyd, P.A. (1977) Geochemical discrimination of different magma series and their differentiation products using immobile elements. Chemical Geology, 20, 325-343. 
D. R. N. ROSA ET AL.

Appendix:

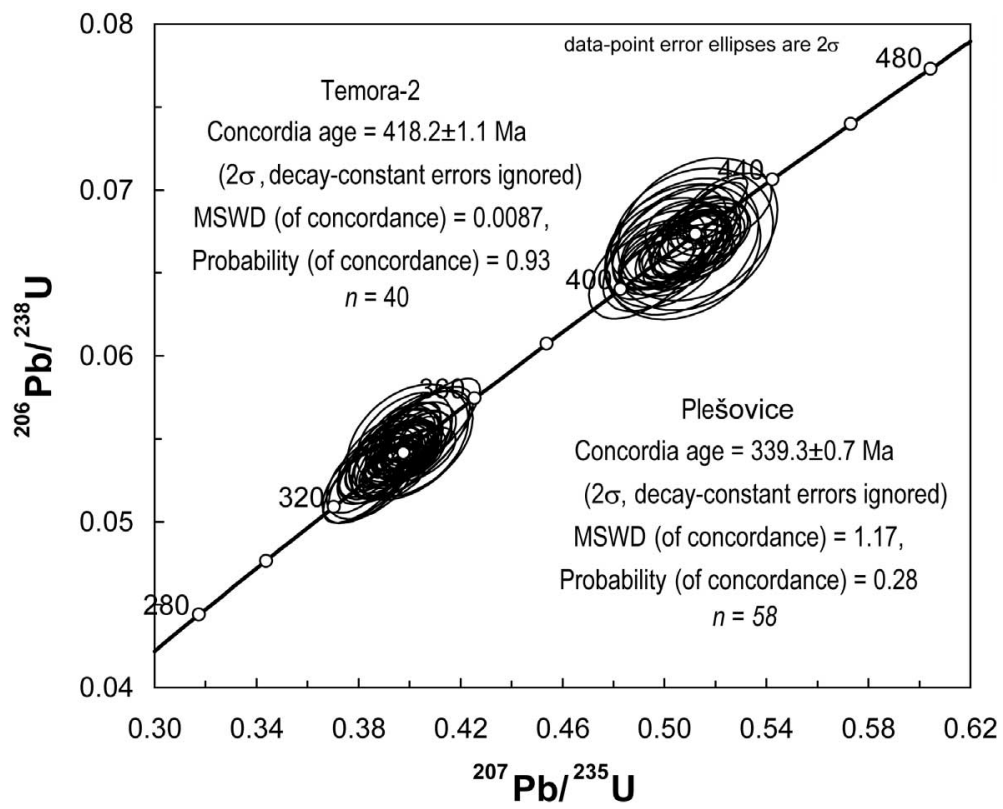

FIG. A1. Reference zircons Temora-2 (TIMS-ID U-Pb age: 416.8 \pm 1.3 Ma; Black et al., 2004 ) and Plešovice (TIMSID U-Pb age: $337.1 \pm 0.4 \mathrm{Ma}$; Sláma et al., 2008) run as unknowns.

Table A1. U-Pb data for standard zircons Temora-2 and Plešovice run as unknowns. (deposited) 